Finnes det en særegen muslimsk fruktbarhet eller befolkningspolitikk som er direkte påvirket av religionen islam? Er høy muslimsk fruktbarhet uunngåelig? Eller er den muslimske holdningen til fødselstall og familieplanlegging ikke styrt av religion, men av sosiale og politiske forhold?

\title{
Myten om den muslimske fødselsmaskinen
}

Ragnhild Klafstad er religionshistoriker fra Universitet i Oslo. Hun har skrevet masteroppgaven «Den muslimske fødselsmaskinen, en orientalistisk myte? En undersøkelse av befolkningspolitikken 
TEKST: Ragnhild Klafstad

DET ER EN UTBREDT forestilling at fødselstallene blant muslimer er vesentlige høyere enn hos andre religiøse grupper. Islam blir således forklaringen på høye barnetall uten at dette problematiseres eller forklares. En går ut i fra at det er "noe" i islam som medfører høy fruktbarhet uten at en vet hva dette "noe" er. For eksempel skriver Jahn Otto Johansen i sin Signert-spalte i Aftenposten 28. januar 2008 at unge muslimske kvinner i Europa skaffer seg høyere utdannelse og vil ikke være "fødemaskiner".

Med denne observasjonen sier han samtidig at unge muslimske kvinner som ikke bosetter seg i Europa fortsetter å være "fødemaskiner".

Begrepet "den muslimske fødselsmaskin" er ment som en metafor på en oppfatning om at islam automatisk medfører høye fødselstall. Begrepet fødsels- maskin eller fødemaskin henviser til en forståelse av kvinner som "ikke-mennesker" uten rettigheter, tanker eller følelser, som kun er til stede på jorden for å føre menneskerasen videre. En slik forståelse reduserer muslimske kvinner til kun produsenter av barn uten noen form for selvinnsikt eller forståelse av verden. Denne forståelsen av muslimske kvinner reduserer samtidig muslimske menn til å bare være avlsdyr. En slik redusering av muslimske kvinner kan en for eksempel finne i Hallgrim Bergs «Amerikabrevet: Europa i fare» (2007). ${ }^{2}$ Denne beskrivelsen av muslimske menn og kvinner er med på å forme et bilde av muslimer som religiøse roboter, vesentlig forskjellig fra oss selv. Det skaper en "vi og de andre"-oppfatning av verden, hvor "vi”, som hvite og vestlige er mer rasjonelle, logiske og fornuftige enn "de andre". Muslimene blir oppfattet som ikke å være i stand til å ta egne beslutninger basert på logiske resonnementer. Jeg mener forståelsen av "vi" og "de andre" er ettervirkninger av orientalismen. Edward Said demonstrerte gjennom «Orientalismen» hvordan orienten fremstilles som degenerert og med et behov for ledelse. Ifølge Said fører dette til en sammenblanding av forskning og politikk som fremdeles preger enkelte av dem som forsker på samtidens Midtøsten. ${ }^{3}$

Jeg hevder at det ikke finnes en bestemt muslimsk befolkningspolitikk eller fruktbarhet. I stedet vil jeg påpeke at det er de muslimske landenes ${ }^{4}$ ulike politiske kontekst som er med på å forme både befolkningspolitikken og som avgjør i hvilken grad islam påvirker denne. Jeg vil åpne denne artikkelen med en historisk gjennomgang av den juridiske diskursen rundt prevensjon i islam. Dette for å vise at tanker om 
fødselskontroll og prevensjon ikke er en ny vestlig oppfinnelse fra det 20. århundre, men er tankemateriell som stammer fra islams tidlige historie. Jeg vil så beskrive hvordan prevensjon og familieplanlegging diskuteres i dag, og argumentere for at antall barnefødsler i muslimske land ikke er en direkte følge av religionen islam, men at andre forhold som politisk kontekst, velferdstilbud og landenes historie er med på å styre befolkningsveksten. Jeg vil til slutt illustrere dette med Iran. Iran er et spennende land demografisk sett fordi det har gjennomgått flere ulike befolkningspolitiske perioder. Iran eksemplifiserer også at en islamsk stat kan satse på familieplanlegging og å få en generell støtte for dette i den muslimske befolkningen.

\section{Prevensjon i islam}

Ifølge Basim Mussallam, forfatteren av boken «Sex and society in islam» (I983), er ekteskapet som seksuell institusjon nøkkelen til å forstå en mengde relaterte emner, for eksempel prevensjon. Han beskriver den historiske og juridiske debatten omkring prevensjon i muslimsk tradisjon, og peker på store religiøse forskjeller mellom kristendom og islam i forståelsen av ekteskap og prevensjon i middelalderen. I kristen tradisjon var ekteskapene monogame og permanente, oppløselige kun ved døden. I muslimsk tradisjon var ekteskap polygamiske og oppløselige gjennom skilsmisse. Forståelsen av ekteskap som oppløselige og muligheten for sex med konkubiner (kvinnelige slaver) var faktorer som medførte at fødselskontroll ble tillatt i middelalderen i den muslimske verden.

I Koranen finnes det ingen referanser til prevensjon. I hadither, korte fortellinger om profeten Muhammeds liv og tradisjon, finner en de tidligste islamske kildene som omtaler prevensjon. Disse la grunnlaget for senere diskusjoner i islam om prevensjon. Det finnes flere hadither om fødselskontroll, spesielt omhandlende azl eller coitus interuptus, det vil si avbrutt samleie. Begge disse metodene betyr uttrekning, at mannen trekker seg ut av kvinnens vagina før utløsning.

I en hadith spør en soldat om det er lov å praktisere avbrutt samleie på de kvinnelige fangene. Muhammed gir sitt samtykke til dette, for hvis Gud vil skape noe er det ingen mann som kan hindre ham. ${ }^{5}$ I en annen hadith som demonstrerer Guds vilje til å kunne skape liv sier profeten; "selv om du søler sæd som var ment skulle bli til et barn på en stein, vil Gud lage barn av denne steinen." ${ }^{\prime}$ Begge disse hadithene vektlegger predestinasjon og Guds uinnskrenkede makt, den første også at profeten direkte tillot fødselskontroll.

Coitus interuptus var den eneste prevensjonsmetoden som ble diskutert i islamsk rettslære. Årsaken til dette kan være at alle juristene var menn, og at coitus interuptus er en mannlig prevensjonsmetode. Medisinsk litteratur og Bassim Mussalam viser imidlertid at kvinner benyttet seg av en rekke andre prevensjonsmetoder. Disse metodene kunne være forskjellige innsprøytninger og ulike typer tamponger.?

Professor i kvinnestudier Leyla Ahmed hevder at historisk sett var den juridiske konklusjonen om å tillate prevensjon i islam en tolkning som gagnet både menn og kvinner. Den gav kvinner kontroll over og lov til å forhindre og tidsbestemme graviditeter. Menn var økonomisk ansvarlige for alle etterkommere. Dette gjorde det økonomisk gunstig for menn å få så få 
barn som mulig. Motsatt var det for kvinner en fordel å få så mange barn som mulig. Uten barn fantes det ingen økonomiske utsikter ved skilsmisse og barn gjorde det også mer problematisk for mannen å skille seg. ${ }^{8}$

Debatten i islamsk rettshistorie viser at prevensjon og fødselskontroll ikke er nytt tankemateriale i den muslimske verden. Tvert imot viser den historiske debatten at ideen om å kontrollere barnetallet har vært diskutert blant muslimske lærde siden profeten Muhammeds tid på 6oo-tallet. Denne debatten mellom lærde om bruken av prevensjon kan imidlertid ha foregått på avstand fra både lekmenn og kvinner. Men kvinner, som nevnt ovenfor, benyttet seg av en rekke metoder som ikke er nevnt $\mathrm{i}$ de juridiske diskusjonene. Momenter som økonomi og ønske om barn kan ha vært like viktige begrunnelser som religiøs tillatelse i beslutninger om å anvende prevensjon.

I moderne tid har kvinnelige prevensjonsmidler i stor grad erstattet mannlige. Men juristene bruker samme type logikk i religiøs tillatelse av prevensjon som sine forgjengere. Sunni- og shia-jurister har benyttet seg av qiyas, analogi, og hevdet at siden prevensjon, forstått som avbrutt samleie, har vært tillatt i islam vil man gjennom analogi tillate moderne former for prevensjon som p-piller og spiral. Majoriteten av muslimske lærde mener familieplanlegging er tillatt når mann og kone i enighet benytter seg av prevensjon. ${ }^{9}$

Enkelte jurister hevder imidlertid at prevensjon ikke er tillatt $i$ islam. De argumenterer med en hadith som sier; "gift dere og få mange barn og jeg vil være stolt av dere på dommenes dag." ${ }^{\prime \circ}$ Juristene har et deterministisk utgangspunkt og hevder familieplanlegging er i mot Guds vilje. Disse juristene etterlyser en sterkere tillit til at Gud vil bistå menneskene. Mye av opposisjonen mot familieplanlegging blant nåtidens muslimske lærde er imidlertid like mye et utslag av politikk som religion. Familieplanlegging blir forstått som en del av Vestens forsøk på å kontrollere den muslimske verden. Denne type argumentasjon hevder at Vesten ønsker å svekke islam ved å senke antallet muslimer i verden. ${ }^{\text {II }}$

En del av den muslimske opposisjonen mot familieplanlegging kom til utrykk på FNs befolkningskonferanse i Kairo i I994.

\section{Familieplanlegging blir forstått som en del av Vestens forsøk på å kontrollere den muslimske verden.}

På denne konferansen var fokuset flyttet fra makro- til mikronivå. Fokuset var ikke, som tidligere, på enkelte land, og hva overbefolkning vil føre til når det gjaldt økonomiske utvikling, miljøkonsekvenser eller nasjonal fattigdom. I stedet var oppmerksomheten rettet mot hvilke konsekvenser det å få mange barn har for den enkelte kvinne, kvinners posisjon mer generelt, og retten til prevensjon som ett av flere aspekter ved reproduktiv helse. Den politiske friksjonen på denne konferansen oppstod ikke på det praktiske planet, men på et ideologisk plan. Uenighetene oppstod mellom kvinnegrupper som ønsker reproduktive rettigheter, og en religiøs allianse som bestod av Vatikanet, antiabortgrupper og enkelte muslimske stater. Fire muslimske land endte med å boikotte konferansen; Saudi-Arabia, Libanon, Irak og 
Sudan. Alliansen mellom Vatikanet og muslimske land hadde imidlertid for ulike politiske målsettinger til å kunne holde sammen. ${ }^{\text {.2 }}$

Det var også et flertall av muslimske stater som støttet konferansen. Det var likevel boikotten av enkelte muslimske land som fikk mest mediedekning, noe som bidro til å forsterke bildet av muslimer og islam som lite endringsvillige og tradisjonelt i mot prevensjon og familieplanlegging. Dette bildet av muslimer underbygger forståelsen av "vi og de andre", hvor "vi" er logiske og moderne med lave fødselstall og "de andre", med høye fødselstall, blir forstått som umoderne og kvinnene blir sett på som fødselsmaskiner uten selvinnsikt. Jeg mener høye fødselstall ikke er synonymt med umoderne eller ikkevestlig. Norge har for eksempel lenge jobbet for å øke fødselstallene gjennom ulike velferdspolitiske tiltak som fødselspermisjon og barnetrygd. Jeg vil nå presentere en tabell som viser myndighetene i ulike muslimske land sitt syn på fødselstallene og deres prevensjonspolitikk (se neste oppslag).

\section{Fødselstall og befolkningspolitikk}

Denne tabellen er interessant fordi den demonstrerer store variasjoner i muslimske lands fødselstall og befolkningspolitikk. Første kolonne viser størrelsen på befolkningen, kolonne nummer to viser andel muslimer. Tredje kolonne viser total fruktbarhetsrate, det vil si gjennomsnittlig antall barn per kvinne gjennom livet. Den fjerde kolonnen viser myndighetenes syn på fruktbarhetsnivået. Siste kolonne viser myndighetenes politiske linje i støtte til tilgang på prevensjon enten direkte gjennom offentlige utsalg og distribusjon, eller indi- rekte gjennom støtte til andre forhandlere. FN har siden I970-tallet regelmessig innhentet opplysninger om myndigheters syn på fruktbarhet og befolkningspolitikk. Ifølge FN-rapporten World Population Policies 2003 oppgir ingen islamske land at de aktivt begrenser innbyggernes tilgang til og informasjon om familieplanlegging. ${ }^{13}$

Jeg vil nå gå nærmere inn i tallmaterialene for ett av landene. Iran er et spennende befolkningspolitisk land fordi det har endret politikk flere ganger. Iran har hatt et bemerkelseverdig fall i fruktbarheten fra en total fruktbarhetsrate på seks barn per kvinne på midten av ı980tallet til et gjennomsnitt på 2,I barn per kvinne i 200I. Iran er et eksempel på et muslimsk land som med støtte fra det religiøse etablissementet har brukt ulike insentiver for å senke fødselstallene.

\section{Befolkningspolitikk i Iran}

Befolkningspolitikken i Iran har vært preget av landets skiftende politiske historie. Tre ulike befolkningspolitiske perioder utpeker seg; en antinatalistisk periode under Pahlaviregimet I967-1977, en pronatalistisk periode i I977-I989, og igjen en antinatalistisk politikk innført av det sittende islamske styret i I989. Natalisme betyr fødselshyppighet, antinatalistisk politikk ønsker å senke fødselhyppigheten, mens pronatalistisk politikk har som mål å øke fødselshyppigheten.

\section{Under sjahen 1967 til 1979}

Et familieplanleggingsprogram ble igangsatt av myndighetene i I967. Dette programmet hadde to hovedstrategier: Den ene var å øke kvinners sosiale og juridiske status og deltagelse i samfunnet. Dette ble gjort gjennom "familiebeskyttelselover" 

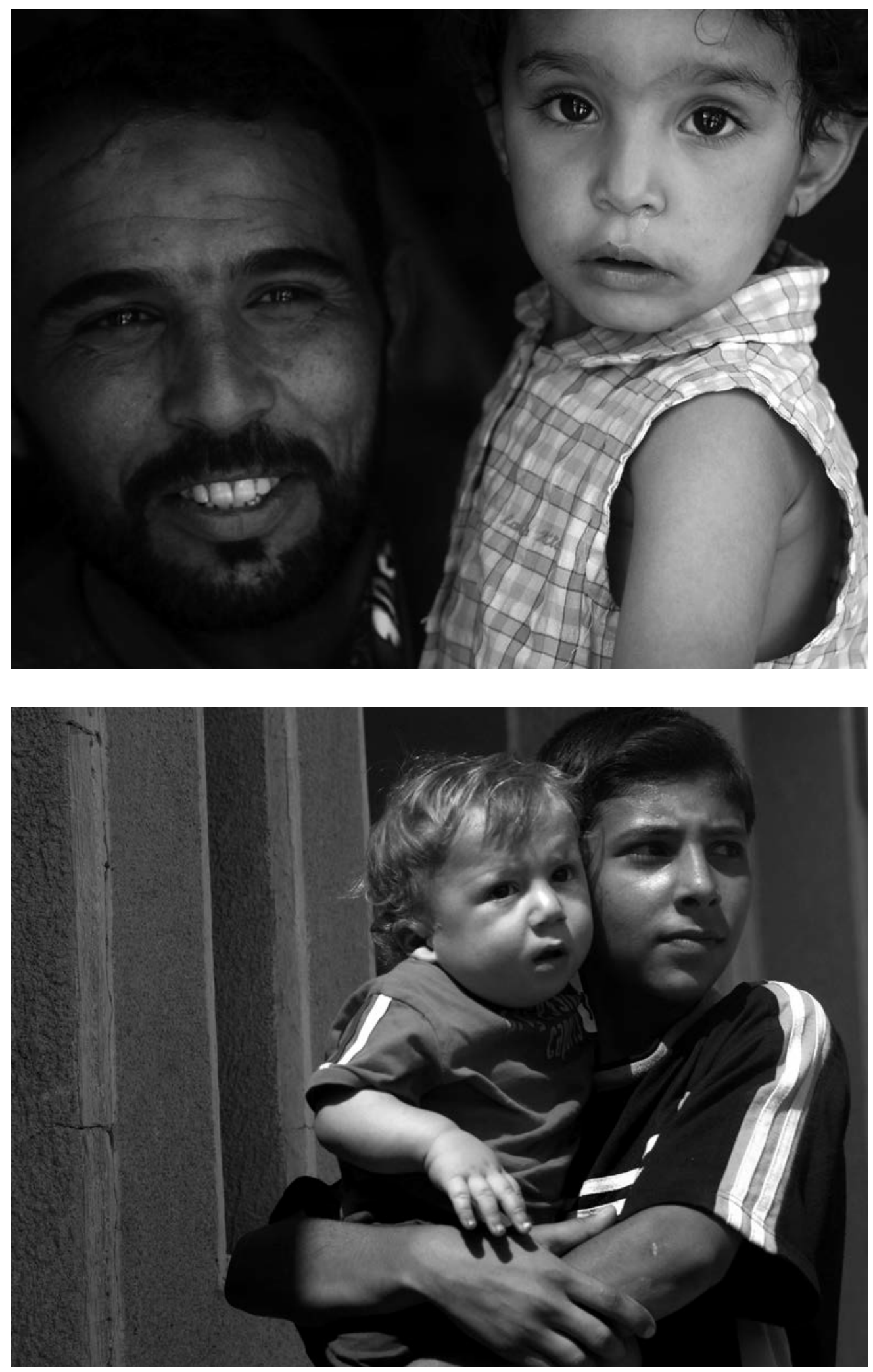
Land

Befolkning i millioner*

Prosentvis muslimsk

befolkning*

\begin{tabular}{|c|c|c|}
\hline Afghanistan & 24,8 & 99 \\
\hline Algerie & 30 & 99,9 \\
\hline Azerbaijan & 7,7 & 93,4 \\
\hline Bahrain & 0,6 & 81,8 \\
\hline Bangladesh & 127,6 & 88,3 \\
\hline Djibouti & 0,7 & 97,2 \\
\hline Egypt & 63,3 & 90 \\
\hline Emiratene & 2,7 & 96 \\
\hline Gambia & 1,3 & 95 \\
\hline Guinea & 7,5 & 86,9 \\
\hline Indonesia & 203 & 87,2 \\
\hline Iran & 61,5 & 99 \\
\hline Irak & 21,7 & 97 \\
\hline Jemen & 16,4 & 99,9 \\
\hline Jordan & 4,7 & 96,5 \\
\hline Komorene & 0,5 & 99,3 \\
\hline Kuwait & 1,9 & 85 \\
\hline Libya & 5,7 & 97 \\
\hline Maldivene & 0,3 & 100 \\
\hline Mali & 10,1 & 90 \\
\hline Mauritania & 2,5 & 99,5 \\
\hline Marokko & 28,1 & 99,8 \\
\hline Niger & 9,7 & 88,7 \\
\hline Oman & 2,4 & 87,7 \\
\hline Pakistan & 141,9 & 95 \\
\hline Qatar & 0,6 & 95 \\
\hline Saudi-Arabia & 20,8 & 96,6 \\
\hline Senegal & 9,7 & 92 \\
\hline Somalia & 6,8 & 99,9 \\
\hline Sudan & 33,6 & 72 \\
\hline Syria & 15,3 & 86 \\
\hline Tajikistan & 6,1 & 85 \\
\hline Tunisia & 9,4 & 99,5 \\
\hline Tyrkia & 64,6 & 99,8 \\
\hline Turkmenistan & 4,7 & 87 \\
\hline Usbekistan & 16,4 & 88 \\
\hline
\end{tabular}


Fruktbarhetsrate ${ }^{* * *}$

Myndighetenes syn

på fruktbarhetsraten ***

6,8

2,5

1,8

2,7

3,3

5,9

3,2

2,5

5,6

6,0

2,6

2,0

5,0

7,0

3,7

6,8

4,0

3,6

3,7

7,0

5,9

2,5

8,0

4,1

4,8

4,0

4,8

5,1

5,1

5,4

3,8

3,1

2,0

2,5

2,9

2,9
Tilfredsstillende

For høy

Tilfredsstillende

Tilfredsstillende

For høy

For høy

For høy

For lav

For høy

For høy

For høy

For høy

Tilfredsstillende

For høy

For høy

For høy

Tilfredsstillende

Tilfredsstillende

For høy

For høy

Tilfredsstillende

For høy

For høy

For høy

For høy

Tilfredsstillende

Tilfredsstillende

For høy

Tilfredsstillende

For høy

Tilfredsstillende

For høy

For høy

For høy

Tilfredsstillende

Tilfredsstillende
Myndighetenes policy på

tilgang på prevensjon $* *$ *

Indirekte støtte

Direkte støtte

Direkte støtte

Direkte støtte

Direkte støtte

Direkte støtte

Direkte støtte

Ingen støtte

Direkte støtte

Direkte støtte

Direkte støtte

Direkte støtte

Direkte støtte

Direkte støtte

Direkte støtte

Direkte støtte

Indirekte støtte

Ingen støtte

Direkte støtte

Direkte støtte

Direkte støtte

Direkte støtte

Direkte støtte

Ingen støtte

Direkte støtte

Direkte støtte

Indirekte støtte

Direkte støtte

Indirekte støtte

Direkte støtte

Direkte støtte

Direkte støtte

Direkte støtte

Direkte støtte

Ingen støtte

Direkte støtte

$* *$ ROUdi-FAHIMi, FARZANEH (2004) “ISLAM AND FAMILY PLANNING”, Side 7. 
som ble innført på I960- og 70-tallet. Disse lovene skulle gjøre det vanskeligere for mannen å få skilsmisse og begrense polygami ved at ektemannen måtte ha enten konas eller rettens tillatelse for å kunne inngå flere ekteskap. Videre skulle disse lovene giøre det enklere for kvinner å få omsorgen for barn ved skilsmisse. Kvinner ble også sosialt og juridisk oppfordret til å søke jobb utenfor hjemmet. ${ }^{14}$

Den andre strategien i familieplanleggingsprogrammet var å distribuere prevensjonsmidler direkte. Distribusjonen ble utvidet, fra å tidligere kun omfatte kom-

\section{Ekteskapet som seksuell institusjon er en nøkkel til å forstå relaterte emner som prevensjon.}

mersiell sektor til å også bli distribuert gjennom offentlige helsesentre. Det ble igangsatt store mediekampanjer for å promotere prevensjon på midten av I970-tallet. Statistikk viser at antall brukere av prevensjon økte i perioden I967 til I977, fra 0,02 prosent til II prosent. Når det gjelder motivet for familieplanlegging viser en undersøkelse at majoriteten av brukerne begynte å bruke prevensjon når de hadde oppnådd ønsket barnetall, fremfor å forlenge perioden mellom to fødsler. Videre var bruken av prevensjon ujevnt fordelt $i$ befolkningen. Kvinner i urbane strøk med utdanning var de mest sannsynlige brukerne av prevensjon. ${ }^{15}$

Undersøkelser viser at fruktbarheten hadde en liten økning i denne perioden fra 5,8 barn per kvinne i I972 til 6, o barn per kvinne i I976. Fruktbarhetsnivået foran- dret seg ikke spesielt mye, til tross for familieplanleggingsprogrammet. ${ }^{16}$ Grunnen til at det var vanskelig å implementere programmet $\mathrm{i}$ befolkningen, er det blitt hevdet, var at programmet ikke tok hensyn til samfunnets sosiokulturelle og religiøse kontekst. $^{\text {I7 }}$

\section{Krigen mot Irak I979 til I988}

Etter revolusjonen i I979 hersket det en pronatalistisk stemning i landet. Total fruktbarhetsrate økte fra 6,o levende fødte barn per kvinne i I976 til 7,0 i I984. Flere faktorer bidro til dette, blant dem tendensen til å starte familie tidlig, endring av lover og reguleringer for å oppmuntre til flere barn, sterke fremtidshåp og en tro på at myndighetene skulle sørge for helse, skole og mat til alle.

En viktig katalysator for den høye fruktbarheten var krigen mot Irak, som varte fra I980 til I988. Under krigen ble familier oppfordret til å få flere barn, for å oppfostre flere soldater til skapelsen av "tjue millionerarmeen". ${ }^{\text {. }}$ Økonomiske insentiver ble iverksatt for å oppnå dette, blant annet gjennom et rasjonaliseringssystem av varer. Dette systemet dekket ikke bare mat, klær og andre husholdningsartikler, men også varer og gjenstander som tv, kjøleskap og lignende. Jo større familie, jo større rasjon. Dette gjorde det gunstig med mange barn.

Etter revolusjonen var fremtiden for familieplanlegging avhengig av de religiøse ledernes godkjennelse. Ayatollah Khomeini ble kontaktet og bedt om å komme med en fatwa, en juridisk-religiøs erklæring, vedrørende prevensjon. I februar I980 avga Khomeini en fatwa, som godkjente prevensjon under to betingelser: at metoden ikke skulle skade kroppen, og at ekte- 
mannen måtte godkjenne bruken av prevensjonsmidlet. ${ }^{19}$ Denne fatwaen førte til omorganisering av familieplanleggingsklinikkene, som fremdeles ble drevet av helsedepartementet. Prevensjon fortsatte å være gratis, men på grunn av krigen og handelsboikott av Iran, fantes det kun i en begrenset mengde. ${ }^{\circ}$ Det ble heller ikke gjennomført noen form for markedsføring av tjenesten. Selv om det ikke ble gitt noen informasjon om tjenesten, var antall kvinnelige brukere av familieplanleggingssentrene økende under krigen. ${ }^{2 \mathrm{I}}$ Tall viser at fruktbarheten var raskt voksende etter revolusjonen, men begynte å synke allerede i I984, fire år før krigen mot Irak var over. Fra en total fruktbarhetsrate på 7 barn per kvinne i I984 sank tallet til 6,2 i I986 og videre til 5,5 i ig $88 .^{22}$

\section{Fra 1988 og frem til i dag}

I I986 ble det lagt frem tall som viste at Irans befolkning nærmet seg 50 millioner, og at befolkningen vokste med mer enn tre prosent $\mathrm{i}$ året. Videre var 45 prosent av befolkningen under I4 år. Dette ble først tatt imot som en gledelig nyhet. At befolkning hadde nådd 50 millioner, erklærte statsminister Mir Hodeyn Musavi for en av den islamske revolusjonens største ervervelser. $^{23}$

Plan- og budsjettetaten, som har ansvar for å planlegge og å overvåke de andre departementene, forutså hvilke problemer en så sterk befolkningsvekst kunne medføre. De samlet data angående hva det ville koste å bygge opp landet og samtidig opprettholde det nødvendige tilbudet til befolkningen. Disse tallene fremla de for myndighetene. Statsministeren svarte med å be alle departementer å vurdere befolkningsvekstens virkning $\mathrm{i}$ forhold til den første utviklingsplanen som skulle fremlegges i i989. Senere innrømmet han at myndighetene hadde skiftet synspunkt på befolkningsvekst. ${ }^{24}$

Etter å ha overbevist flere politikere om viktigheten av familieplanlegging, bestemte plan- og budsjettetaten i samarbeid med helsedepartementet å lansere en kampanje for å overbevise andre politikere og befolkningen om viktigheten av å ha en nasjonal befolkningspolitikk. Dette var ingen lett oppgave. Flere av de ledende politikerne hadde tidligere opponert mot shaens befolkningspolitikk. Utfordringen lå i å få til et skifte i politisk retning uten at de religiøse og politiske lederne mistet $\sin$ legitimitet. ${ }^{25}$

Et ledd i denne kampanjen var offentlig opplysning og debatt om befolkningsspørsmål for å få den offentlige opinionen til å utøve press på regimet og de religiøse ledere. Eksperter og intellektuelle tilknyttet plan- og organisasjonsetaten skrev artikler hvor de pekte på kostnader og konsekvenser ved en vedvarende og økende ung befolkning. Flere ministere ble overbevist om viktigheten av en god befolkningspolitikk, og disse ga intervjuer hvor de pekte på de problemene befolkningsvekst kunne ha for områder som utdanning, helse, matproduksjon, og kollektivtransport. I debatten fikk også opponentene mot familieplanlegging lov til å si sin mening. Flere aviser trykket intervjuer og leserinnlegg hvor det ble hevdet at familieplanlegging var imperialisme og et ønske om å redusere antall muslimer. Som svar på dette hevdet andre i debatten at målet ikke var å redusere befolkningen, men å styrke Irans utvikling. Fruktbarhetskontroll var bare en liten del av den nasjonale utviklingsplanen. ${ }^{26}$ 
Videre måtte også myndighetene opplyses om befolkningsspørsmål. Det ble avholdt møter mellom tekniske eksperter og religiøse ledere. Disse møtene handlet om landets ressurser målt opp imot økonomisk vekst og kostnadene ved befolkningsvekst. Det ble understreket at befolkningspolitikk innebar moralske og etiske aspekter som de religiøse lederne måtte ta ansvar for. Flere religiøse ledere svarte med å påpeke at det ikke finnes noe forbud i islam mot prevensjon eller mot et ønske om færre barn. ${ }^{27}$

Plan- og organisasjonsetaten avholdt et tre dagers seminar i september I988. Her hjalp iranske medier til med å distribuere hovedbudskapet om at Irans befolkningsvekst var for høy, og at hvis det ikke ble igangsatt tiltak, ville denne veksten ha en sterk negativ effekt på landets økonomi og velferd. På slutten av seminaret ble det avholdt en pressekonferanse hvor Khomeinis fatwa fra I980 ble sitert, og det ble samtidig annonsert at Iran ville starte et familieplanleggingsprogram. ${ }^{28} \mathrm{I}$ desember I988 erklærte vokterrådet at det ikke fantes noen islamske hindringer for familieplanlegging.

\section{Religiøs opposisjon}

Blant shiamuslimske lærde i Iran har det ikke vært noen opposisjon mot myndighetenes familieplanleggingsprogram. De religiøse lederne har kommet med fatwaer som sanksjonerer prevensjon og har benyttet fredagsbønnen til å oppfordre innbyggerne til å fullføre sitt sosiale ansvar, oppsøke familieplanleggingstilbudet fra myndighetene og få færre barn. ${ }^{29}$

I Iran har sunnimuslimske afghanske flyktninger høyere fødselstall enn den shiamuslimske iranske befolkningen. Dette har ført til spekulasjoner om det er sektriske forskjeller innen islam som fører til forskjellige fødselstall. Diane M. Tober, Mohammed-Hossein Taghdisi og Mohammad Jalali har i en artikkel undersøkt religiøs opposisjon mot familieplanleggingsprogrammet hos afghanske sunnimuslimske flyktninger. På grunn av krig og uro i Afghanistan befinner det seg nå opptil 2,5 millioner registrerte afghanske flyktninger og omkring 500 ooo uregistrerte flyktninger i Iran..$^{\circ}$ Ifølge de iranske helsearbeiderne benytter afghanske flyktninger seg ikke av familieplanleggingsprogram og tilbud om prevensjon. Dette blir forklart med at de er sunnimuslimer, og at prevensjon er mot deres religion. Men ifølge Tobin et al. kan ikke sekteriske forskjeller i islam forklare ulik bruk av prevensjon. De skriver:

"Religious interpretations and cultural differences may have an impact on reproductive decision making, but religion itself does not seem to preclude the use of family planning in these cases." ${ }^{11}$

For Iran, som aktivt prøver å begrense sin befolkningsvekst, blir afghanske flyktningers store familier og reservasjon mot familieplanlegging sett som en økonomisk utfordring. Iranske myndigheter har med støtte fra FNs flyktningorganisasjon trappet opp hjemsendelsen av afghanske flyktninger. Irans økonomiske problemer som inflasjon, høy arbeidsledighet, økning i skatter for å betjene flyktningkostnader og en stor ungdomsbefolkning, har medført sterke spenninger mellom iranere og afghanske flyktninger. For afghanere som føler seg marginalisert i det iranske samfunnet oppfattes familieplanleggingspro- 
grammet, selv om det retter seg i like stor grad mot iranere, som en del av myndighetenes repatriering av afghanere.

Dette er i tråd med min hypotese om at det er den politiske konteksten som er avgjørende. Den politiske konteksten marginaliserer de afghanske flyktningene og bidrar til oppfatningen om at iranerne vil redusere antall afghanere gjennom familieplanleggingsprogrammet.

\section{Religion som påvirkningskraft}

Kevin McQuillan peker i sitt forskningsmateriale på tre elementer som må være tilstede for at religion skal kunne påvirke fruktbarhet. ${ }^{32}$ Det første av disse er at religionen må artikulere normer som er tilknyttet fruktbarhetsresultat. Slike normer kan være direkte bestemmelser angående prevensjon og abort, men også mer generelle forhold relatert til kjønnsroller og familie.

Den religiøse gruppen må også kommunisere og følge opp disse verdiene og normene gjennom et sanksjonsapparat som kan straffe de som ikke følge normene og premiere de som følger dem. Til slutt vil disse normene ha sterkest påvirkningskraft på de religiøse medlemmene som har en sterk tilhørighet til det religiøse fellesskapet. Det er religionens institusjonelle påvirkningskraft McQuillan vektlegger. Denne institusjonelle påvirkningskraften ved religion synliggjøres på tre områder: i storsamfunnet, i lokalsamfunnet og i hvert enkelt individs liv.

I Iran spiller islam spiller en dominerende rolle i organiseringen av samfunnet. Etter den islamske revolusjonen i I979 skal all lovutforming være i samsvar med islam, inkludert lover vedrørende familieplanlegging, seksuell kontakt, helseprogram og skoletilbud. Videre er det i Iran i stor grad geistlige som blir politikere. Det var religiøse ledere som ble politikere etter revolusjonen, og hele det politiske systemet bygger på en kombinasjon av religion og politikk. Derfor vil all statlig politikkutforming være i samsvar med iranske geistliges tolkning av islam og sharia. Myndighetenes politikk må i denne politiske konteksten forstås som "riktig" tolkning av shiaislam og shiaislamsk lov.

Da det på myndighetsnivå var oppnådd konsensus vedrørende lovligheten av familieplanlegging i islam, ble religiøse institusjoner brukt for å videreformidle dette til befolkningen. Moskeer i hele landet ble brukt til å spre informasjon om familieplanleggingsprogrammet. I rurale områder

\section{Sekteriske forskjeller innen islam kan ikke forklare ulik bruk av prevensjoner.}

var dette spesielt nyttig, da lokale prester ofte hadde bedre muligheter til å informere fattige, ikke-utdannede iranere som var skeptiske til myndighetenes offisielle befolkningsprogram. Også det offentlige skolevesenet sprer informasjon og kunnskap om familieplanlegging og prevensjon. På alle undervisningsnivåer, inkludert universitetene, foregår det skolering i familieplanlegging.

Det er bestemt ved lov at all seksuell omgang utenfor ekteskapet, zina, er forbudt. Zina kan i Iran straffes med fengsling, bøter, pisking og steining. For å kunne ha seksuell omgang må en være gift. Et giftemål er ikke gyldig før det er registr- 
ert hos myndighetene som slik holder oversikt over hvilke par som er og hvilke som ikke er legitime. Når preventiver ble utdelt på helsestasjoner, ble det tidligere spurt om sivilstatus, for å sjekke om du var i et legitimt forhold som ga deg rett til prevensjon. I samtale med tidligere leder av familieplanleggingsprogrammet, dr. Bahram Delavar, opplyste han om at det nå ikke lenger spørres om sivilstatus blant annet på grunn av redsel for spredning av hiv.

Iran har hatt en sterk satsing på familieplanlegging og har vektlagt at hver familie må ta ansvar for nasjonens økonomiske

\section{Prevensjon og familieplanlegging er ikke nye ideer i den muslimske verdenen.}

utvikling. Et par får ikke økonomiske bidrag fra staten for flere enn tre barn. Videre blir det sosialt sett ned på å få flere barn. Under mitt opphold ved universitetet i Teheran fortalte de andre studentene meg om en professor som hadde fire barn og de mente at han og hans kone var egoistiske og uansvarlige, ettersom de fikk så mange barn.

Lignende holdninger finnes i forhold til afghanske flyktninger, som i gjennomsnitt får flere barn enn iranere. I begge tilfellene blir det oppfattet som egoistisk at en bruker en større del av statens ressurser og ikke tar hensyn til myndighetenes krav om lavere befolkningsvekst.

De sosiale normene i stor- og lokalsamfunnet for hvilke antall barn som er "riktig”, gir en sterk føring på individers valg av familiestørrelse. Jeg tror likevel motivene for å følge statens befolkningspolitiske linje er forskjellige ut fra den enkelte iraners klassetilhørighet, utdanningsnivået og hvilken del av landet en kommer fra.

\section{Avslutning}

Jeg har her forsøkt å vise at ideen om en “muslimsk fødselsmaskin" og en særegen islamsk fruktbarhet bestående av høye fødselstall er falsk. Prevensjon og familieplanlegging er ikke nye ideer i den muslimske verdenen. Som historien viser, har diskursen rundt prevensjon og fødselskontroll vært ført blant muslimske lærde på 700-tallet. I den moderne debatten rundt islam og prevensjon er politiske og historiske kontekster med på å forme de forskjellige muslimske landenes forhold til og mål i befolkningspolitikken.

Enkelte muslimske land har høy fruktbarhet og ønsker av ulike grunner dette. For eksempel har land i den arabiske regionen som ønsker å øke fødselstallene vektlagt økonomi. Disse var alle oljeeksporterende land med et sterkt behov for arbeidskraft. Disse landene valgte, i likhet med Norge, å skape forhold som førte til høyere fødselstall i egen befolkning fremfor å importere arbeidskraft fra andre land. Andre muslimske land har lav fruktbarhet og bruker ulike politiske virkemidler aktivt for å oppnå lave fødselstall. Iran er et eksempel på et muslimsk land som ønsker lav befolkningsvekst.

Jeg har i denne artikkelen beskrevet Irans befolkningspolitikk og hvilke politiske virkemidler som er tatt i bruk for å oppnå lave fødselstall. Eksemplet Iran viser at det er mulig for et muslimsk land å oppnå lave fødselstall hvis det føres en politikk som legger til rette for dette.

Iran er ikke eksepsjonelt som et mus- 
limsk land med lave fødselstall og aktiv befolkningspolitikk. Som det kommer frem i tabell $\mathrm{I}$, finnes det flere andre muslimske land med lave fødselstall. Sammenhengen mellom islam og fruktbarhet er komplekst og kontekststyrt og kan ikke forklares gjennom enkle metaforer som “den muslimske fødselsmaskinen”.

\section{- $f$ •}

I Johansen, Jahn Otto: “Blir Europa islamifisert?”, i Aftenposten, Oslo, 28. januar 2008

2 Berg, Halgrim: «Amerikabrevet: Europa i fare». Oslo: Koloritt forlag, 2007

3 Said, Edward: «Orientalisme, vestlige oppfatninger av orienten», Oslo: De norske bokklubbene, 200I

4 Jeg definerer et muslimsk land som et land hvor flertallet av befolkningen er muslimer, og en islamsk stat som et land med en direkte henvisning til sharia, den islamske loven i landets konstitusjon.

5 Ahmed, Leila: «Women and Gender in 1slam», New Haven \& London: Yale University Press, s. 64, I992, Mussalam, Basim: «Sex and society in Islam», Cambridge: Cambridge university press, 1983 , s. Io

6 Mussalam: 1983, s. I6, min oversettelse

7 Mussalam: 1983, s. 37f, Esposito, Jhonn L.: "Family Planning" i Esposito Johnn L (red): The Oxford Encyclopaedia of Modern Islamic World, New York : Oxford University Press, vol I, I995, S. 464-465

8 Ahmed: I992, s. 92f

9 Esposito, Jhonn L.: «The Oxford Dictionary of Islam», New York: Oxford University Press, 2003, s. 44

Io Esposito: 1995, s. 465, min oversettelse

II Esposito: 1995, S. 465

I2 Stein, Dorothy: «People who count Population and politics women and children», London: Earthscan publications Ltd, I995, s. 27, Johnson, Stanley: «The politics of population The international conference on population and development Cairo I994", London : Earthscan publications Ltd, I995, s. $79 \mathrm{f}$

I3 Roudi-Fahimi Farzaneh: "Islam and family planning" i Mena policy brief, Population Reference Bureau, 2004 www.prb.org, Goverment of Islamic country er i artikkelen brukt som betegnelse, jeg har valgt å oversette dette med islamske land da det er uklart om artikkelforfatteren mener muslimske eller islamske land, se note 4

I4 Hoodfar, Homa og Assadpour, Samad: "The politics of population policy in the Islamic Republic of Iran", i Studies in Family Planning, Vol 20, $\mathrm{Nr}$ I, 2000, s. 19-34
I5 Aghajanian, Akbar: "Family Planning and Contraceptive Use in Iran, I967-1992", i International Family Planning Perspective, Vol 20, $\mathrm{nr}$ 2, 1994, s. 66-69

I6 Abbasi-Shavazi, Mohammed J. og McDonald, Peter: "National and Provincial-level fertility trends in Iran, 1972-2000", i Working Papers in Demography no 94, Demography and sociology program, Australian national University, 2005, S. I-4I

I7 Abbasi-Shavazi, Mohammed J.: "The fertility revolution in Iran”, i Population Societies, Nr 373, 200I, S. I-4

I8 Abbasi-Shavazi, Mohammed J.: 200I, S. I, "twenty million army", min oversettelse

I9 Ladier-Fouladi, Marie: "The fertility transition in Iran", i Population: an English selection, Vol 9, I997, s .19I-213

20 Aghajanian, Akbar og Merhyar, Amir H: "Fertility, Contraception Use and family planning program Activity in the Islamic republic of Iran", i International Family Planning perspective, $\mathrm{Vol} 25, \mathrm{Nr} 2$, I999, s. 98-10

2I Ladier-Fouladi, I997, S. 20 I

22 Abbasi-shavazi og McDonald 2005

23 Obermeyer, Carla Makhlouf: "Reproductive choice in Islam: Gender and state in Iran and Tunisia", i Studies in Family Planning, Vol 25, Nr I, I994, S.4I-5I

24 Roudhi-Fahimi, Farzaneh: "Irans family planning program: responding to a nation needs", i Mena policey briefs, population reference Bureau, 2002, www.prb.org

25 Hoodfar \& Assadpuor: 2000, s. 22

26 Hoodfar \& Assadpuur: 2000, s. 22

27 Hoodfar \& Assadpuur: 2000 , s. 24

28 Aghajanian, Akbar: 1994, s. 67

29 Aghajanian \& Merhyar: I999, S. I02, Roudi: I999, s. 9

30 Tober, Diana og Taghdisi, Mohammed-Hossein og Jalali, Mohammad: "'Fewer Children, Better Life" or As Many as Gods Wants" ?: Family Planning among Low-income Iranian and Afghan Refugee families in Isfahan, Iran", i Medical Anthropology Quarterly, Vol 20, Nr I, 2005, s. 5072

3I Tober et al: 2005, s. 62

32 McQuillan, Kevin: "When does Religion Influence Fertility?", Population and development Review, Vol 30, Nr I, 2004, s. 25-56, McQuillan, Kevin: «Culture, Religion and Demographic Behaviour Catholics and Lutherans in Alsace, I750-I870», Montreal : McGill-Queen`s University Press, 1999 